\title{
Studi Klinis Infeksi COVID-19 pada Kehamilan dengan Insulin Dependent Diabetes Mellitus (IDDM)
}

\author{
Arif Rahman Nurdianto ${ }^{1,2 *}$, Rizal Fauzi Nurdianto ${ }^{3}$, Dyah Ayu Febiyanti ${ }^{4}$ \\ Public Health Office of Sidoarjo ${ }^{1}$ \\ Departement of Medical Laboratory Technology, STIKES Rumah Sakit Anwar Medika, \\ Sidoarjo, Indonesia ${ }^{2}$ \\ Student of Medical Faculty Universitas Wijaya Kusuma Surabaya, Indonesia ${ }^{3}$ \\ Department of Pharmacy, General Hospital of Sidoarjo, Indonesia ${ }^{4}$ \\ *e-mail: didins99@gmail.com
}

\begin{abstract}
Abstrak
Penelitian terhadap kehamilan dengan insulin dependent diabetes mellitus (IDDM) yang terinfeksi COVID-19 sangat terbatas. Pada kondisi hamil terdapat pergeseran Th1 ke arah Th2 dan perubahan fisiologis yang menyebabkan pada kondisi hamil sangat rentan terinfeksi COVID-19 disamping keluhan yang mirip antara perubahan akibat kehamilan dengan gejala COVID-19. Studi ini bertujuan untuk menjelaskan pengaruh infeksi COVID-19 pada ibu hamil dengan komorbid IDDM. Studi ini dilakukan dengan metode deskriptif terhadap hasil pemeriksaan klinis dan laboratoris pasien hamil yang berusia 26 th dengan IDDM dan terinfeksi COVID-19 di Puskesmas Trosobo sejumlah satu orang. Variabel dalam studi ini adalah hasil pemeriksaan klinis dan laboratorium pasien selama menjalani pengobatan. Seluruh data kemudian dilakukan analisis deskriptif sesuai dengan literatur jurnal yang terbaru. Dari studi didapatkan hasil ibu hamil dengan IDDM dan terinfeksi COVID-19 dapat menunjukkan gangguan pada organ paru berupa gambaran pneumonia pada rontgen dan gangguan pada hasil laboratorium serta gangguan klinis yang ringan. Selain itu perlu diperhatikan adanya gangguan jantung yang ditunjukkan dengan gangguan irama EKG post partum. Infeksi COVID19 pada ibu hamil dengan IDDM dapat menunjukkan gejala ringan maupun berat seperti gangguan pada jantung nya dan diperlukan penelitian lebih lanjut mengenai pengaruh infeksi tersebut dengan sampel yang lebih besar.
\end{abstract}

Kata Kunci: COVID-19, Insulin dependent diabetes mellitus, kehamilan, Th1, Th2

\section{Clinical Study Covid-19 Infection in Pregnancy with Insulin Dependent Diabetes Mellitus (IDDM)}

\begin{abstract}
Research on pregnancies with insulin dependent diabetes mellitus (IDDM) infected with COVID19 is very limited. In pregnant conditions, there is a shift from Th1 to Th2 and physiological changes that make it very susceptible to being infected by COVID-19 in pregnancy, in addition to complaints that are similar between changes due to pregnancy and symptoms of COVID-19. The aim of this study was to Explain the effect of COVID-19 infection in pregnant women with IDDM. This study was conducted using a descriptive method of clinical and laboratory examination results of one pregnant patient aged 26 years with IDDM and infected with COVID-19 at the Trosobo Health Center. The variables in this study were the results of clinical and laboratory examinations of patients during treatment. All data were then analyzed
\end{abstract}


Studi Klinis Infeksi COVID-19 pada Kehamilan dengan Insulin Dependent Diabetes Mellitus...

Arif Rahman Nurdianto, Rizal Fauzi Nurdianto, Dyah Ayu Febiyanti

descriptively according to the latest journal literature. Result of this study showed that Pregnant women with IDDM and infected with COVID-19 might have disorders of the lung organs in the form of pneumonia on X-rays, disturbances in laboratory test and minor clinical disorders. In addition, it is important to note that the presence of heart problems as indicated by disturbances in the rhythm of the post partum ECG. COVID-19 infection in pregnant women with IDDM can show mild or severe symptoms such as heart problems and further research is needed on the effect of this infection with a larger sample.

Keywords: Covid19, insulin independent diabetes mellitus, pregnancy, Th1, Th2

\section{PENDAHULUAN}

Terdapat keterbatasan penelitian terhadap COVID-19 selama kehamilan sedangkan ibu hamil merupakan populasi yang sangat rentan terhadap infeksi COVID-19. Hal tersebut disebabkan karena ibu hamil mengalami perubahan fisiologis dan perubahan mekanis tubuh yang meliputi peningkatan konsumsi oksigen, edema mukosa saluran pernafasan, peningkatan diafragma dan perubahan volume paru selama kehamilan. Semua perubahan tersebut menurunkan total lung capacity (TLC) dan kemampuan tubuh untuk membersihkan saluran pernafasan. Semua kejadian tersebut memperlampat diagnosa COVID-19 pada kehamilan karena kemiripan keluhan selama kehamilan dengan keluhan akibat infeksi (Liang and Acharya, 2020; LoMauro and Aliverti, 2015).

Pada kehamilan terjadi downregulasi dari proliferasi maupun aktivasi limfosit yang menjadikan ibu hamil menjadi kelompok yang rentan akan infeksi COVID19 (Nurdianto et al, 2020a). Infeksi COVID-
19 dapat mengganggu keseimbangan sistem imunitas selama kehamilan pada feto maternal interface.

National health commission of China menyebutkan terdapat 118 ibu hamil selama 8 Desember 2019 hingga 20 maret 2020 dan sebagian besar dan 84 orang diantaranya memiliki hasil PCR positif dan 29 persen memiliki gambaran pneumonia pada hasil CT Scan paru nya. Dari keseluruhan pasien 112 diantaranya memiliki gejala atu simtomatik sedangkan 6 lainnya asimtomatik. Meskipun jumlah nya cukup banyak, tidak ditemukan angka kematian pada ibu hamil saat itu karena 92\% merupakan kasus ringan dan 8 persen kasus sedang dengan 1 ibu hamil menggunakan ventilator. Berdasarkan laporan tersebut 68 pasien lahir dengan sectio cesarea, 3 pasien mengalami abortus, 2 kasus kehamilan ektopik, 14 kasus dengan prematuritas dan tidak ada bayi yang mengalami asfiksia (Chen et al, 2020). Prematuritas dan kematian bayi pada pasien dengan kehamilan dan terinfeksi COVID-19 terjadi pada pasien 
dengan komorbid seperti obesitas, diabetes mellitus, hipertensi dan asma (Lokken et al, 2020).

Kehamilan dengan COVID-19 di Sidoarjo menjadi salah satu masalah tersendiri karena hingga bulan agustus 2020 ini didapatkan 8 pasien hamil yang terkonfirmasi COVID-19 dengan pemeriksaan PCR positif (Dinas Kesehatan Kabupaten Sidoarjo, 2020). Penanganan kasus COVID-19 ini juga memiliki kendala berupa sedikitnya jumlah rumah sakit rujukan untuk kasus kehamilan COVID-19. Hal tersebut dilakukan karena banyak faskes yang tidak menerima persalinan dengan COVID-19. Dari semua kasus diatas didapatkan satu kasus ibu meninggal dan satu bayi meninggal beberapa waktu setelah dilahirkan. (Jawa Pos, 2020)

Hasil pemeriksaan hematologi pasien didapatkan penurunan monosit dan limfosit, total leukosit, peningkatan trombosit dan hemoglobin $(\mathrm{Hb})$, peningkatan laktat dehidrogenase (LDH), serta penurunan kreatinin, fibrinogen dan D-Dimer. (Martinelli et al, 2020).

Terdapat pergeseran imunitas tubuh dari Th1 ke arah Th2 pada ibu hamil (Nurdianto and Suryokusumo 2020), sedangkan Th2 merupakan penghasil sitokin IL-4, IL-10, IL-13, dan TGF $\beta$ yang bertindak sebagai anti inflamasi. (Nurdiyanto et al, 2019). Pergeseran populasi $T$ helper tersebut membuat ibu hamil lebih rentan untuk terinfeksi termasuk terinfeksi SARS-CoV-2.

Infeksi SARS-CoV-2 pada kehamilan merangsang peningkatan ekspresi sitokin proinflamasi yaitu IL-6, IL-12, IL-1 $\beta$, dan IFNY yang dapat merusak organ paru. Pergeseran Th2 yang lebih dominan membuat sitokin anti inflamasi dapat mengimbangi ekspresi sitokin proinflamasi (Nurdianto et al, 2020) seperti IL-6 yang menyebabkan keparahan dan kematian pada pasien COVID-19. Hal ini merupakan penyebab tingkat keparahan COVID-19 pada ibu hamil lebih rendah (Dashraath et al, 2020).

Berdasarkan penjelasan diatas maka pembahasan kasus COVID-19 pada kehamilan ini penting dilakukan agar penanganan kehamilan dengan infeksi virus ini dapat dilakukan dengan hasil kajian ilmiah yang terkini sehingga dapat menekan angka prematuritas atau abortus. Diharapkan penelitian ini bisa dijadikan landasan dalam melakukan riset dan terapi di masa yang akan datang.

Fenomena infeksi COVID-19 pada kehamilan yang memiliki banyak dampak negatif bagi ibu dan janin menunjukkan bahwa penyakit ini masih perlu dikaji lebih dalam. Penelitian ini perlu dilakukan dengan tujuan untuk menjelaskan pengaruh infeksi COVID-19 pada ibu hamil 
Studi Klinis Infeksi COVID-19 pada Kehamilan dengan Insulin Dependent Diabetes Mellitus... Arif Rahman Nurdianto, Rizal Fauzi Nurdianto, Dyah Ayu Febiyanti

yang memiliki penyakit IDDM agar didapatkan hipotesis mengenai mekanisme infeksi COVID-19 pada kehamilan dengan IDDM.

\section{PRESENTASI KASUS}

Studi ini merupakan laporan kasus dengan metode penelitian desktiptif. Kasus merupakan seorang pasien hamil yang berusia 26 th dengan IDDM dan terinfeksi COVID-19 di Puskesmas Trosobo. Pengamatan kasus dilakukan dengan observasi dan analisis terhadap hasil pemeriksaan fisik serta hasil pemeriksaan laboratorium pasien dari awal pasien terinfeksi COVID-19 hingga pasien dinyatakan sembuh setelah melakukan pemeriksaan Reverse Transcriptase Polymerase Chain Reaction (RT-PCR) $2 \mathrm{X}$ negatif (Pemeriksaan ke 6 dan ke-7). Data yang didapatkan dianalisis dan dibahas berdasarkan literatur yang sudah ter publikasi sebelumnya.

Pasien datang berobat ke klinik swasta untuk kontrol rutin kehamilan di tanggal 7 Februari 2020, 6 Maret 2020, 16 Maret 2020, 4 april 2020, dan tanggal 10 April 2020. Pada saat kontrol tersebut pasien sudah merasakan batuk dan demam. Akan tetapi selama masa pasien merasakan keluhan tersebut, pasien tidak pernah melakukan pemeriksaan rapid tes ataupun swab tenggorok.
Pasien datang berobat ke RS untuk memeriksakan kandungan secara rutin pada tanggal 16 April 2020 dengan keluhan batuk dan nyeri tenggorokan yang tidak berhenti. Saat berobat di RS pasien dilakukan pemeriksaan swab. Gambaran rontgen Ny. D (26 th), G2P10001 Usia kehamilan 34-35 minggu tampak multiple focuse infiltrate pada supra parahilar dan paracardial kanan dan kiri yang menunjukkan kesan pneumonia bilateral, multifokal dan multilobar. Dengan hasil tersebut diatas pasien menunjukkan gejala yang sangat khas seperti pasien dengan infeksi COVID-19 tanpa kehamilan.

Dari anamnesa diperoleh bahwa pasien merupakan pasien dengan insulin dependent diabetes mellitus (IDDM) yang terkontrol dengan pemakaian insulin injeksi subcutan. Gambaran Gula Darah Acak (GDA) pada pasien tersebut didapatkan sebesar $113 \mathrm{mg} / \mathrm{dL}$ Kondisi tersebut menunjukkan bahwa pasien memiliki gangguan metabolisme glukosa atau komorbid diabetes mellitus yang terkontrol selama kehamilan ini. Sehingga dengan kondisi komorbid terkontrol ini dapat memberikan peluang pasien menjadi pasien yang tidak menunjukkan gejala ataupun pasien dengan mild symptomatic seperti saat ini.

Hasil pemeriksaan darah lengkap pada Ny. D didapatkan hasil differential 
count sebagai berikut: Neutro $81,8 \%(\mathrm{H}) /$ Lym 9,7\% (L)/ Mon 7,3\% (H) /Eos 0,2\% (L)/ Bas 1\% Dan hasil perhitungan jumlah total sel didapatkan hasil sebagai berikut Neutro $9,25 \times 10^{3}(\mathrm{H}) / \operatorname{Lym} 1,10 \times 10^{3}(\mathrm{~L}) /$ Mon 0,82 $\mathrm{X} 10^{3}(\mathrm{H}) /$ Eos $0,03 \times 10^{3}(\mathrm{~L}) /$ Bas $0,11 \times 10^{3}$. Hasil tersebut menunjukkan bahwa pada pasien ini didapatkan terdapat penurunan dari sel Limfosit dan Eosinofil pada darah nya serta didapatkan peningkatan jumlah neutrophyl serta monosit.

Hasil pemeriksaan darah lengkap dari pasien juga didapatkan hasil darah yang normal dengan kadar PCT: 0,355\%, P-LCC, dengan hasil Plt $405 \times 10^{3} / \mathrm{mL}$. Pada tanggal 16 April 2020 pasien dilakukan pemeriksaan swab yang pertama dan didapatkan hasil RT-PCR positif dan dilanjutkan dengan pemeriksaan RT-PCR kedua pada tanggal 30 April 2020 didapatkan hasil PCR positif.Pemeriksaan RT-PCR dilanjutkan hingga pemeriksaan swab ke-6 dan ke-7 (tanggal 3 dan 17 juni 2020) yang didapatkan hasil $2 X$ pemeriksaan negatif.

\section{PEMBAHASAN}

Pengaruh dari infeksi COVID-19 pada kehamilan masih belum sepenuhnya diketahui karena masih sangat sedikit data yang akurat. Pada pasien ini ditemukan hasil pemeriksaan rontgen yang berupa pneumonia bilateral, multifokal dan multilobar dengan gejala batuk dan nyeri tenggorokan yang tidak berhenti dengan pemberian antibiotik. Gambaran pneumonia ini sulit dibedakan dengan pneumonia akibat bakteri tanpa pemeriksaan RT-PCR. Hal ini sejalan dengan dua penelitian di China yang menunjukkan bahwa karakteristik klinis pneumonia akibat COVID-19 pada ibu hamil sama dengan infeksi pada wanita dewasa yang tidak hamil (Mimouni et al, 2020; Chen et al, 2020). Infeksi tersebut dipermudah terjadi karena pasien tersebut memiliki IDDM yang menyebabkan imunitas pasien lebih rendah dibandingkan pada kehamilan normal.

Gejala batuk ringan dan nyeri tenggorokan ringan menunjukkan bahwa infeksi COVID-19 pada pasien menimbulkan gejala ringan. Hal tersebut sejalan dengan laporan kasus 43 wanita hamil dengan COVID-19 yang menunjukkan bahwa $86 \%$ memiliki gejala ringan, 9,3\% memiliki gejala yang berat dan $4,7 \%$ menjadi penyakit yang serius (Breslin et al, 2020) Penelitian lain menyebutkan sebaliknya bahwa kehamilan dengan pneumonia akibat COVID-19 menunjukkan gejala yang ringan dan penyembuhan yang bagus seperti pada kasus ini (Liu et al, 2020).

Gejala infeksi COVID-19 pada kehamilan pasien ini juga sejalan dengan 
Studi Klinis Infeksi COVID-19 pada Kehamilan dengan Insulin Dependent Diabetes Mellitus... Arif Rahman Nurdianto, Rizal Fauzi Nurdianto, Dyah Ayu Febiyanti

laporan 9 kasus infeksi pada kehamilan trimester 3 di China yang menunjukkan 6 pasien mengalami panas, 3 mengalami nyeri otot, 2 mengalami batuk berdahak dan 2 mengalami malaise. Tidak ditemukan gejala penyakit yang berat atau kematian akibat pneumonia COVID-19 akan tetapi ditemukan fetal disstress pada 2 pasien. Semua pasien melahirkan dengan selamat tanpa ditemukan asfiksia pada bayi yang dilahirkan dan tidak ditemukan virus SARSCoV-2 pada sampel air susu, cairan amnion, darah placenta dan swab tenggorok pada bayi (Chen et al, 2020). Sedangkan pada pasien ini didapatkan gangguan disstress nafas pada bayi saat dilahirkan dengan hasil pemeriksaan rapid test positif pada bayi yang baru dilahirkan.

Pada penelitian 15 wanita hamil dengan COVID-19 didapatkan sebagian besar pasien mengalami panas dan batuk dan hasil limfositopenia pada 12 pasien. Hasil CT-SCAN menunjukkan bahwa ditemukan gambaran ground glass appearance dan tidak menunjukkan perburukan setelah proses kelahiran (Liu et al, 2020; Salehi et al, 2020). Sedangkan pada pasien ini didapatkan gangguan batuk, sesak serta oedema tungkai yang lama tidak teratasi serta gangguan gastritis pada pasien yang menyebabkan intake nutrisi pasien menurun.
Keluhan sesak berulang dan oedema kaki kemungkinan dapat disebabkan oleh gangguan pada Jantung yang kemungkinan disebabkan COVID-19 pada kehamilan dapat meningkatkan potensi terjadinya tromboemboli pada vena terutama pada pasien dengan isolasi dirumah karena kondisi kehamilan alami merupakan kondisi hipercoagulabel (Royal College of Obstetricians \& Gynaecologists, 2020). Oleh karena itu selama pasien melakukan isolasi mandiri di rumah selalu disarankan untuk tetap melakukan aktifitas fisik dengan monitoring dari petugas.

Pada minggu kedua setelah pasien dirawat gerak bayi yang biasanya aktif menjadi menurun dan dilakukan rujukan untuk pemeriksaan kondisi detak jantung janin dan kondisi lain yang mungkin terjadi akibat infeksi COVID-19. Setelah dilakukan pemeriksaan didapatkan kondisi detak jantung janin dalam kondisi baik.

\section{Transmisi dari Ibu Ke Bayi}

Bayi yang dilahirkan pada pasien ini didapatkan hasil pemeriksaan rapid test positif pada hari ke-3 setelah dilahirkan dan didapatkan distress nafas. Hal tersebut menunjukkan bahwa kemungkinan terdapat transmisi virus COVID-19 dari ibu ke bayi. Transmisi vertikal dari ibu ke bayi dimungkinkan pada infeksi COVID-19 pada kehamilan yang ditunjukkan dengan adanya kasus bayi perempuan yang 
ISSN 1978-2071 (Print); ISSN 2580-5967 (Online) Jurnal IImiah Kedokteran Wijaya Kusuma 9(2) : 229-244, September 2020

mengalami kenaikan $\operatorname{lgM} 2$ jam setelah lahir dari ibu dengan COVID-19, hal tersebut menunjukkan bahwa terdapat kemungkinan infeksi saat bayi berada di dalam rahim karena kita tahu bahwa IgM ibu tidak dapat masuk ke darah bayi melalui placenta (Dong et al, 2020; Zeng et al, 2020; Qiao, 2020). Pada penelitian 6 kasus pasien hamil dengan COVID-19 tidak ditemukan hasil PCR swab tenggorok dan serum akan tetapi ditemukan Antibodi IgM pada 2 bayi padahal kita tahu bahwa IgM seharusnya tidak dapat melewati barrier placenta sehingga perlu dilakukan penelitian lebih lanjut mengenai patofisiologi virus terhadap placenta (Zeng et al, 2020).

\section{Persalinan dengan COVID-19}

Tidak ditemukan data mengenai penularan virus melalui sekret vagina sehingga metode persalinan per vaginam maupun sectio secarea dapat dipertimbangkan pada pasien ini dengan beberapa pertimbangan yang akan ditentukan oleh dokter spesialis obstetri dan ginekologi berdasarkan ada atau tidak nya kontra indikasi pada pasien. Bila persalainan dilakukan secara sectio secarea maka harus dipersiapkan dengan sangat matang mengenai pencegahan penularan pada pasien dan petugas. Selain itu pemberian general anestesia sebisa mungkin dihindari dan lebih diutamakan pemberian anestesi epidural serta fetal monitor harus selalu terpasang saat operasi. Pada pasien ini persalinan dilakukan secara sectio secarea oleh spesialis obstetri dan gynaecology dengan menggunakan APD level 3.

Setelah persalinan dilakukan separasi antara ibu dan bayi karena hasil pemeriksaan PCR ibu masih positif dan gejala klinis berupa batuk masih ditemukan Data menunjukkan bahwa 12 ibu hamil terinfeksi SARS-CoV diantaranya mengalami keguguran pada trimester pertama, mengalami Intra uterine Growth Restriction (IUGR) pada trimester 2, mengalami kelahiran prematur, 3 wanita meninggal selama kehamilan dan tidak ditemukan satupun bayi yang terinfeksi SARS-CoV.Sedangkan 10 pasien hamil terinfeksi MERS-CoV memiliki gejala klinis bervariasi dari ringan hingga berat dengan angka kematian bayi sebesar 27\% (Alfaraj et al, 2020). Pada pasien ini didapatkan disstress nafas pada bayi beberapa hari setelah dilahirkan dan didapatkan hasil pemeriksaan rapid test reaktif tetapi belum dilakukan pemeriksaan PCR pada bayi tersebut.

Infeksi COVID-19 pada Ibu hamil saat ini memiliki implikasi yang lebih ringan dibandingkan dengan infeksi SARS-CoV dan MERS-CoV akan tetapi masih terdapat kemungkinan kelahiran prematur setelah 
Studi Klinis Infeksi COVID-19 pada Kehamilan dengan Insulin Dependent Diabetes Mellitus... Arif Rahman Nurdianto, Rizal Fauzi Nurdianto, Dyah Ayu Febiyanti

usia kehamilan 28 minggu (Mullins et al, 2020).

Proposed mechanism covid 19 infection pada kehamilan.

COVID-19 dapat dengan cepat ditularkan melalui airborne dan interpersonal, dapat menyebabkan infeksi saluran pernapasan atas ringan dengan demam, batuk, dan infeksi saluran pernapasan bagian bawah yang dapat berkembang untuk kasus yang parah dan pneumonia yang mengancam jiwa seperti gagal nafas dan atau Acute Respiratory Disstress Syndrome (ARDS) yang menyebabkan kematian. Meskipun memiliki beberapa kesamaan dengan virus korona lain, SARS-CoV-2 lebih menular daripada patogen lain dan saat ini, tidak ada pengobatan target yang efektif untuk virus ini. (Rohmah and Nurdianto, 2020)

Kehamilan merupakan kondisi yang memiliki keunikan dalam perubahan imunologi tubuh. Sangat sedikit sekali data yang menunjukkan adaptasi imunitas tubuh pada kehamilan terhadap infeksi COVID-19. Kondisi kehamilan menjadi kondisi dimana tubuh akan sangat mudah terinfeksi terutama infeksi saluran pernapasan serta infeksi pada kondisi ini dapat meningkatkan angka mortalitas dan morbiditas. Hal tersebut disebabkan pada kehamilan terdapat peninggian diafragma, penekanan rongga thorax, penurunan volume paru sehingga menyebabkan shortness of breath, penurunan kemampuan pembersihan sekeret saluran pernafasan dan peningkatan resiko infeksi yang berat. Selain itu pada kehamilan yang bagus dapat meningkatkan toleransi terhadap fetus sehingga tidak dianggap sebagai antigen asing, dan menyiapkan tubuh untuk mengatasi infeksi mikroba asing yang masuk. Selain itu bertahannya kehamilan juga ditentukan oleh kemampuan tubuh dalam merubah kesetimbanhan Th1 kearah Th2. (Nurdianto et al, 2019a)

Jiao (2020) menyebutkan bahwa hormon dan imun level di setiap trimester kehamilan memiliki perbedaan. Pada trimester awal keseimbangan imun masih belum stabil sehingga pada kondisi infeksi virus dapat menyebabkan gangguan sistem imun dan gangguan lingkungan pada janin yang akhirnya dapat menyebabkan gangguan pertumbuhan janin bahkan abortus (Nurdianto, 2019a; Nurdianto et al, 2019b)

Terdapat pergeseran fisiologis ke arah limfosit T-helper tipe 2 (Th2) pada kehamilan normal, yang ditandai dengan meningkatnya sitokin anti-inflamasi, seperti interleukin (IL) 4, IL-10 , IL-13 dan Transforming Growth Factor Beta (TGF- $\beta$ ). Dashraath et al (2020) Menjelaskan dominasi-Th2 ini dapat berkontribusi 
ISSN 1978-2071 (Print); ISSN 2580-5967 (Online) Jurnal IImiah Kedokteran Wijaya Kusuma 9(2) : 229-244, September 2020

terhadap morbiditas dengan meningkatkan kerentanan ibu terhadap patogen intraseluler seperti virus.

Infeksi COVID-19 yang berat ditemukan badai sitokin, yang ditandai dengan peningkatan IL-2, IL-7, IL-10, granulocyte-colony stimulating factor, Interferon alpha- inducible Protein 10 (IFN $\alpha-I P 10)$ dan TNFa. Liu et al menyatakan bahwa, kehamilan trimester pertama dan ketiga kehamilan memiliki resiko terjadinya severe cytokine storm akibat SARS-CoV-2. Ashokka et al (2020) juga menemukan bahwa cytokine storm juga terkait dengan penyakit komorbid dan terapi di ruang intensive care unit (ICU). Sebaliknya, Dashraath et al (2020) menyebutkan bahwa transisi Th1 kearah Th2 pada kehamilan dapat menghasilkan sitokin anti inflamasi yang akhirnya dapat menghasilkan beberapa kehamilan dengan COVID-19 tidak menunjukkan keparahan yang lebih besar dan hasil klinis yang lebih buruk daripada populasi umum. Karena masih sedikitnya data yang menunjukkan pengaruh dari infeksi COVID-19 pada kehamilan maka diperlukan analisis dengan evidence-based yang lebih banyak lagi.

SARS-CoV-2 hampir sama dengan SARS-CoV akan tetapi beberapa mutasi menyebabkan novel virus ini cepat menyebar seperti hilangnya segmen $8 \mathrm{a}$, segmen $8 b$ yang lebih panjang, segmen $3 b$ yang pendek dan protein Nsp 2 dan 3 yang berbeda. (Wu et al, 2020a, 2020b; Xu et al, 2020a, 2020b). Kemampuan menular novel virus ini disebabkan mutasi Nsp 2 (Angeletti et al, 2020), selain itu terdapatnya furin like cleavage site pada protein $\mathrm{S}$ yang diduga sebagai penyebab tingginya virulensi novel virus ini karena dapat berikatan lebih kuat ke reseptor ACE2 (Coutard et al, 2020). SARS-CoV-2 diduga memiliki mekanisme mirip dengan SARS-CoV dalam memasuki sel host yakni SARS-CoV-2 berikatan dengan ACE2 reseptor pada epitel saluran pernafasan dan alveoli (Liu et al, 2020a, 2020b). Saat virus memasuki sel, ACE2 dipecah oleh ADAM Metallopeptidase Domain 17 (ADAM17) di sitoplasma. Penurunan ACE2 ini berhubungan dengan injury alveoli dan meningkatkan permeabilitas paru ( $\mathrm{Li}$ and Clercq, 2020) akibat konversi Angiotensin I menjadi Angiotensin 2 yang merupakan regulator negatif dari jalur renin angiotensin. Angiotensin II akan memicu terbentuknya Angiotensin II Tipe I reseptor (AT1R) yang berakibat pada kerusakan paru yang ditunjukkan dengan distress nafas pada pasien (Li and Clercq, 2020) dimana pada pasien ini kondisi distres nafas tidak ditemukan. Terdapat beberapa kemungkinan yang menyebabkan keluhan sesak nafas tidak muncul meskipun 
Studi Klinis Infeksi COVID-19 pada Kehamilan dengan Insulin Dependent Diabetes Mellitus... Arif Rahman Nurdianto, Rizal Fauzi Nurdianto, Dyah Ayu Febiyanti

didapatkan gambaran pneumoni bilateral pada kedua paru. Beberapa kemungkinan yang dapat diteliti lebih lanjut yakni peran ADAM17 pada pasien dengan kehamilan, jumlah ACE2 reseptor pada pasien hamil hingga proses pembentukan ATIR yang dapat menurunkan gejala hingga tidak terjadi distress nafas. Selain itu perlu juga dilakukan riset mengenai peran hormon dan sel imunitas selama kehamilan dalam menghadapi infeksi SARS-CoV ini sehingga tidak didapatkan keluhan yang berat.

Saat virus memasuki sel, protein ORF3a terbentuk dan akan berinteraksi dengan TRAF3 serta mengaktifasi jalur NFkB sehingga menghasilkan transkripsi gen pro IL-1ß (Siu et al, 2019), selain itu ORF3a dengan TRAF3 akan merekrut kompleks inflamasome yang terdiri dari NLRP3, ASC dan caspase-1. Sinyal kedua yang dihasilkan saat virus masuk sel yakni influx $\mathrm{Ca} 2+$, aktifasi caspase, produksi ROS dan kerusakan mitokondria yang akan merangsang perubahan pro IL-1 $\beta$ menjadi IL-1 $\beta$ yang nantinya akan merangsang produksi sitokin. Kemungkinan pada pasien ini kerja dari NLRP3 atau inflamasome, influx Ca2+, aktifitas caspase, produksi ROS dan kerusakan mitokondria dapat dikendalikan oleh sistem imunitas tubuh sehingga produksi proinflamatory sitokin yang menyebabkan badai sitokin akibat aktifasi IL-1 $\beta$ dapat dicegah sehingga keluhan yang ditemukan pada pasien ini lebih ringan dibandingkan dengan pasien COVID-19 yang lain (Rohmah and Nurdianto, 2020; Nurdianto et al, 2019a,2019b).

Pada SARS-CoV-2 juga masih terdapat Protein ORF8b yang ukurannya lebih panjang dan protein $E$ yang dapat mengaktifkan jalur inflamasome NLRP3 (Shi et al, 2019; Nieto-Torres et al, 2015). Proses tersebut dapat menyebabkan produksi badai sitokin pada pasien dengan infeksi SARS-CoV-2. Semua jalur diatas akan menyebabkan badai sitokin yang menyebabkan distress nafas pada COVID19 , selain itu masih terdapat jalur JNK yang diaktifkan oleh ORF3a, ORF3b dan ORF7a yang merangsang proinflamatory cytokine yang menyebabkan kerusakan paru masif (Liu et al, 2014) akan tetapi kemungkinan jalur tersebut dapat dikendalikan oleh sistem imunitas pada pasien tersebut sehingga didapatkan keluhan mild symptomatik. Selain itu mungkin diperlukan penelitian lebih lanjut mengenai peran dari sel Treg, Th1 dan Th2 dan beberapa komponen imunitas tubuh yang dapat mencegah timbulnya gejala yang lebih berat pada kehamilan.

Kasus menarik pada pasien ini adalah ditemukan peningkatan tekanan darah dengan rerata sistole diatas $140 \mathrm{mmHg}$ dan tekanan darah diastole diatas $100 \mathrm{mmHg}$, 
selain itu juga didapatkan pitting oedema setelah persalinan. Keluhan lainnya adalah munculnya keluhan sesak selama isolasi post partum. Setelah pasien pulang dari isolasi dilakukan pemeriksaan pemeriksaan elektrokardiografi untuk melihat keluhan sesak tersebut dan didapatkan gambaran EKG old myocard infark antero lateral dan inferior luas. Hal tersebut menunjukkan bahwa infeksi virus COVID-19 ini kemungkinan dapat menyebabkan gangguan koagulasi darah yang dapat menyebabkan beberapa gangguan pada arteri koronaria pada jantung sehingga dapat menyebabkan trombus pada beberapa arteri koronaria. Akibat trombus tersebut maka akan terjadi sumbatan yang mengakibatkan terjadinya infark myocard yang mengakibatkan gangguan pada jantung yang digambarkan dengan kelainan pada EKG pasien tersebut. Melihat kejadian tersebut maka perlu diberikan perhatian khusus untuk kewaspadaan terhadap terjadinya hipercoagulable state yang muncul akibat infeki COVID19 baik pada kehamilan maupun tidak terutama pada pasien hamil dengan IDDM yang terinfeksi COVID-19

Kemungkinan gangguan old myocard infarction ini disebabkan oleh peningkatan D-dimer dan adanya gangguan koagulasi sehingga menyebabkan terjadinya komplikasi trombo emboli pada arteri coronaria pasien COVID-19 tersebut. Pada penelitian lain menyebutkan, meskipun pasien mendapat terapi profilaksis antikoagulan, kejadian tromboemboli vena dan arteri hampir mencapai $8 \%$. Penggunaan heparin, khususnya pada pasien dengan peningkatan D-dimer dan skor Sepsis Induced Coagulopathy (SIC) pada kehamilan mungkin memiliki efek yang baik (Negri et al, 2020)

\section{Kebijakan Daerah Dalam Penangan COVID-19 di Sidoarjo}

Dengan melihat kejadian tersebut maka dinas kesehatan kabupaten sidoarjo melakukan langkah langkah preventif dengan mebuat suatu kebijakan untuk melakukan skreening ibu hamil lebih dini terhadap resiko terinfeksi COVID-19 dan melakukan pemeriksaan triple eliminasi (HIV, Sifilis dan Hepatitis B) kemudian melakukan entri pada aplikasi kesehatan. Semua ibu hamil yang memiliki usia kehamilan 37 minggu dilakukan pemeriksaan rapid test untuk skreening COVID-19. Pasien akan dilakukan pengambilan sampel swab nasofaring dan orofaring untuk pemeriksaan Reverse Transcriptase-Polymerase Chain Reaction (RT-PCR) pada fasilitas Container Swab yang dimiliki oelh Dinas Kesehatan Kabupaten Sidoarjo. Pemeriksaan tersebut bisa dilakukan dalam waktu 24 jam dalam kondisi kasus emergency (persalinan 
Studi Klinis Infeksi COVID-19 pada Kehamilan dengan Insulin Dependent Diabetes Mellitus... Arif Rahman Nurdianto, Rizal Fauzi Nurdianto, Dyah Ayu Febiyanti

kpasien kontak erat yang menunjukkan gejala klinis) dan pemeriksaan sesuai waktu normal sesuai antrian antara 4 hingga 5 hari. Seetelah hasil keluar maka petugas medis di Puskesmas akan dapat melakukan rujukan pasien ke Rumah sakit yang sudah ditunjuk oleh dinas kesehatan dan dilakukan persalinan sesuai protokol COVID-19.

\section{KESIMPULAN}

Respon imun pada kehamilan memiliki peran yang sangat penting pada proses melawan infeksi COVID-19. Ibu hamil yang terinfeksi COVID-19 dapat asimptomatik maupun simtomatik tergantung kondisi imunitas tubuh. Ibu hamil dengan penyakit penyerta insulin dependent diabetes mellitus yang terinfeksi COVID-19 dapat menunjukkan gejala ringan dan diduga dapat menyebabkan gangguan lain pada jantung ibu hamil yang berupa gangguan pada rekam jantung. Terdapat kemungkinan transmisi vertikal dari ibu ke fetus selama kehamilan dengan COVID-19 serta diperlukan penelitian lebih lanjut mengenai aspek imunologis pada kehamilan dengan COVID-19.

\section{UCAPAN TERIMA KASIH}

Terima kasih kepada Dinas Kesehatan Kabupaten Sidoarjo yang telah membantu dalam penulisan case report ini.

\section{DAFTAR PUSTAKA}

Alfaraj SH, Al-Tawfiq JA, Memish ZA, 2019. Middle East Respiratory Syndrome Coronavirus (MERSCoV) Infection during Pregnancy: Report of Two Cases \& Review of the Literature.J Microbiol Immunobiol Infect. 52(3): 501503.

Angeletti $S$, Benvenuto $D$, Bianchi $M$, Giovanetti, M, Pascarella $S$ et al, 2020. COVID-2019: the Role of the nsp2 and nsp3 in its Pathogenesis. J. Med. Virol. 2020, 1-5.

Ashokka B, Loh MH, Tan CH, Su LL, Young $B E$, Lye DC et al 2020. Care of the Pregnant Woman with COVID-19 in Labor and Delivery: Anesthesia, Emergency Cesarean Delivery, Differential Diagnosis in the Acutely III Parturient, Care of the Newborn, and Protection of the Healthcare Personnel. Am J Obstet Gynecol. 223(1): 66-74

Breslin N, Baptiste C, Gyamfi-Bannerman C, Miller $\mathrm{R}$, Martinez $\mathrm{R}$ et $a l$, 2020. Coronavirus Disease 2019 Infection among Asymptomatic and Symptomatic Pregnant Women: Two Weeks of Confirmed Presentations to an Affiliated Pair of New York City Hospitals. American Journal of 
Obstetrics \& Gynecology MFM. 2(2): $100-118$

Chen L, Li Q, Zheng $D$, Jiang $H$, Wei $Y$ et al, 2020. Clinical Characteristics of Pregnant Women with Covid-19 in Wuhan, China. Nengl $j$ med. 382(25): 1-3.

Chen H, Guo J, Wang C, Luo F, Yu X et al, 2020. Clinical Characteristics and Intrauterine Vertical Transmission Potential of COVID-19 Infection in Nine Pregnant Women: a Retrospective Review of Medical Records. The Lancet. 395(10226): 809-815.

Coutard B, Valle C, de Lamballerie X, Canard B, Seidah N et al, 2020. The Spike Glycoprotein of The New Coronavirus 2019-Ncov Contains a Furin-Like Cleavage Site Absent in Cov of the Same Clade. Antivir Res. 176, 104742.

Dashraath P, Wong Jப, Lim MXK, Lim LM, Li

S, Biswas A et al, 2020. Coronavirus Disease 2019 (COVID19) Pandemic and Pregnancy. Am J Obstet Gynecol. 222(6): 521-531. Dinas Kesehatan Kabupaten Sidoarjo. 2020. Laporan Kasus Kehamilan Dengan COVID-19 Agustus 2020.

Dong L, Tian J, He S, Zhu C, Wang J et al, 2020. Possible Vertical Transmission of SARS-CoV-2 From an Infected Mother to Her Newborn. JAMA. 323(18): 18461848.

Jawa Pos. 2020.RS di Sidoarjo Wajib Terima Bumil Positif. Jawa Pos; 18 Juli 2020. Diambil dari https://www.jawapos.com/surab aya/18/07/2020/rs-di-sidoarjowajib-terima-bumil-positif-covid19/

Liang $\mathrm{H}$ and Acharya G, 2020. Novel Corona Virus Disease (COVID-19) in Pregnancy: What Clinical Recommendations to Follow?. Acta Obstet Gynecol Scand. 99 (4): 439-442.

Jiao J, 2020. Under the Epidemic Situation Of COVID-19, Should Special Attention to Pregnant Women be Given?. J Med Virol. 92: 13711372.

Li G and Clercq ED, 2020. Therapeutic Options for the 2019 Novel Coronavirus (2019-nCoV). Nat Rev Drug Discov. 19, 1449-14150.

Liu D, Li L, Wu X, Zheng D, Wang J et al, 2020. Pregnancy and Perinatal Outcomes of Women With Coronavirus Disease (COVID-19) Pneumonia: A Preliminary Analysis. American Journal of Roentgenology. 215(1): 127-132. 
Studi Klinis Infeksi COVID-19 pada Kehamilan dengan Insulin Dependent Diabetes Mellitus... Arif Rahman Nurdianto, Rizal Fauzi Nurdianto, Dyah Ayu Febiyanti

Liu DX, Fung TS, Chong KK-L, Shukla A, Hilgenfeld R, 2014. Accessory Proteins of SARS-CoV and Other Coronaviruses. Antivir Res. 109: 97-109.

Liu H, Wang LL, Zhao SJ, Kwak-Kim J, Mor G et al. 2020. Why are Pregnant Women Susceptible to COVID-19? An Immunological Viewpoint. J Reprod Immunol. 2020. 139: 103122.

Liu YT, Chen HW, Lii CK, Jhuang JH, Huang CS et al, 2020a. A Diterpenoid, 14-Deoxy-11, $12-$

Didehydroandrographolide, in Andrographis Paniculata Reduces Steatohepatitis and Liver Injury in Mice Fed a High-Fat and Highcholesterol Diet. Nutrients. 12(2): 523.

Liu Z, Xiao X, Wei X, Li J, Yang J et al, 2020b. Composition and Divergence of Coronavirus Spike Proteins and Host ACE2 Receptors Predict Potential Intermediate Hosts of SARS-Cov-2. J Med Virol. 92(6): 595-601.

Lokken EK, Walker CL, Delaney S, Kachikis A, kretzer NM et al, 2020. Clinical Characteristics of 46 Pregnant Women with a Severe Acute Respiratory Syndrome Coronavirus 2 Infection in
Washington State. Am J Obstet

Gynecol. 2020: 1.e1-1.e14

LoMauro A and Aliverti A, 2015. Respiratory Physiology of Pregnancy: Physiology Masterclass. Breathe (Sheffield, England). 11(4): 297-301.

Martinellia I, Ferrazzib E, Ciavarella A, Errab $\mathrm{R}$, lurlarob $\mathrm{E}$ et al, 2020. Pulmonary Embolism in a Young Pregnant Woman with COVID-19. Thromb Res. 191: 36-37.

Mimouni F, Lakshminrusimha S, Pearlman SA, Raju T et al, 2020. Perinatal aspects on the covid-19 Pandemic: A Practical Resource for Perinatal-neonatal Specialists. Journal of Perinatology. 40(5): 820-826.

Mullins E, Evans D, Viner RM, O'Brien $P$, Morris E, 2020. Coronavirus in Pregnancy and Delivery: Rapid Review. Ultrasound in Obstetrics \& Gynecology. 55: 586-592.

Negri EM, Piloto BM, Morinaga LK, Jardim CVP, Lamy SAE, et al 2020. Heparin Therapy Improving Hypoxia in COVID-19 Patients - a Case Series. medRxiv.

Nieto-Torres JL, Verdiá-Báguena C,JimenezGuardeño JM, Regla-Nava JA, Castaño-Rodriguez C et al, 2015. Severe Acute Respiratory 
Syndrome Coronavirus E Protein

Transports Calcium Ions and

Activates the NLRP3

Inflammasome. Virology, 485, 330-339.

Nurdianto AR, Aryati S, Suryokusumo MG, 2019a. Downregulates of ICAM1 expression in Myometrium from Pregnant Rattus norvegicus Infected with Tachyzoite of Toxoplasma gondii with Hyperbaric Oxygen Therapy. Hang tuah medical journal. 17: 77-83.

Nurdianto AR, Aryati, Suryokusumo MG, Mufasirin, 2019b. Effect of Hyperbaric Oxygen Therapy to IFN Gamma and TNF Alpha Expression In Pregnant Rattus novergicus Infected with Tachyzoite Of Toxoplasma gondii. Bali Medical Journal, 8(1): 94-100.

Nurdianto AR, Aryati, Suryokusumo MG, Mufasirin, Suwanti LT et al, 2020a. Effect of Hyperbaric Oxygen Therapy on ICAM-1 Expression in Artery Spiralis of Pregnant Rattus Norvegicus Infected by Tachyzoite From Toxoplasma gondii. EurAsian Journal of BioSciences Eurasia J Biosci. 14(1): 1757-1762. Nurdianto AR, Aryati, Suryokusumo MG, Mufasirin, Suwanti LT, Sunarjo, Sardjono TW, Dachlan EG, 2020b.
Effects of Hyperbaric Oxygen Therapy on IL-17, Fetal Body Weight and Total Fetus in Pregnant Rattus norvegicus Infected with Tachyzoite Toxoplasma gondii. Systematic Reviews in Pharmacy. 11(3): 628634.

Qiao J, 2020. What are the Risks of COVID19 Infection in Pregnant Women?. The Lancet. 395(10226): 760-762.

Rohmah MK and Nurdianto AR, 2020. Perspective of Molecular Immune Response of SARS-COV-2 Infection. Jurnal Teknologi Laboratorium. 9(1): 58-66.

Royal College of Obstetricians \& Gynaecologists. Coronavirus (COVID-19) infection and pregnancy Version 7. 9 April 2020.

Salehi S, Abedi A, Balakrishnan S, Gholamrezanezhad A, 2020. Coronavirus Disease 2019 (COVID19): A Systematic Review of Imaging Findings in 919 Patients. American Journal of Roentgenology: 1-7.

Siu KL, Yuen KS, Castaño-Rodriguez C, Ye ZW, Yeung ML et al, 2019. Severe Acute Respiratory Syndrome Coronavirus ORF3a Protein Activates the NLRP3 
Studi Klinis Infeksi COVID-19 pada Kehamilan dengan Insulin Dependent Diabetes Mellitus... Arif Rahman Nurdianto, Rizal Fauzi Nurdianto, Dyah Ayu Febiyanti

Inflammasome by Promoting TRAF3-dependent Ubiquitination of ASC. FASEB J. 33: 8865-8877.

Shi C-S, Nabar NR, Huang N-N, Kehrl JH, 2019. SARS-Coronavirus Open Reading Frame-8b Triggers Intracellular Stress Pathways and Activates NLRP3 Inflammasomes. Cell. Death. Discov. 5, 1-12.

Wu A, Peng $Y$, Huang $B$, Ding $X$, Wan $X$ et al, 2020a. Genome Composition and Divergence of the Novel Coronavirus (2019-Ncov) Originating In China. Cell Host Microbe. 27, 325-328.

Wu C, Liu Y, Yang Y, Zhang P, Zhong W et al, 2020b. Analysis of Therapeutic Targets for SARS-Cov-2 and Discovery of Potential Drugs by Computational Methods. Acta Pharm Sin B. 10(5): 766-788.
Xu J, Zhao S, Teng T, Abdalla AE, Zhu W et al, 2020a. Systematic Comparison of Two Animal-To-Human Transmitted Human Coronaviruses: SARS-Cov-2 and SARS-Cov. Viruses. 12, 244.

Xu X, Yu C, Qu J, Zhang L, Jiang $S$ et al, 2020b. Imaging and Clinical Features of Patients with 2019 Novel Coronavirus Sarscov-2. Eur J Nucl Med and Mol Imaging, 1-6.

Zeng Hui, Xu C, Fan J, Tang Y, Deng Q et al, 2020. Antibodies in Infants Born to Mothers With COVID-19 Pneumonia. JAMA. 1323(18): 1848-1849. 